\title{
Nomination process and gender equality in corporate governance bodies
}

\author{
Francesca Gennari \\ Department of Economics and Management \\ University of Brescia \\ Italy \\ francesca.gennari@unibs.it
}

\begin{abstract}
This contribution explores the role of board committees for the gender balance in the corporate governance bodies. The EU and member States have dealt with the issue of women's presence on boards with different approach and tools. The board's gender composition and the members' compensation are steps of a process that begins with the choice of candidates to be included in a list. In this context, board committees can have an important role for the promotion of a sharper gender equality in corporate governance bodies.
\end{abstract} boards

Keywords - Gender equality, corporate governance, women on

\section{GENDER BALANCE ON BOARD AND NOMINATION} PROCESS

In recent years, EU has showed interest in the corporate governance best practices. In this context, the gender equality in the composition of the corporate bodies was a point of attention (e.g. Recommendation 96/694/EC; COM(2010)78; COM(2010)491; Women on the Board Pledge for Europe, the European Pact for Gender Equality 2011-2020; Europe 2020 Strategy). To date, fifteen member States have adopted binding or self-regulatory standards. In particular, Austria, Belgium, Denmark, Finland, France, Greece, Italy, Netherlands, Portugal, Slovenia and Spain decided to introduce legislative or administrative binding rules. Germany, Luxembourg, Sweden and UK opted for voluntary initiatives, recommendations or Ministerial proposals. Thirteen states do not require any kind of intervention (Bulgaria, Cyprus, Croatia, Czech Republic, Estonia, Hungary, Ireland, Latvia, Lithuania, Malta, Portugal, Romania and Slovakia).

Considering this situation and the low percentage of women on boards [1] [2], [3], the European Commission has decided to intervene in a more incisive way. It has proposed a legislative obligation (Directive 2012/0299 (COD), with the aim of reaching the critical threshold of 30 percent of women on boards by 2015 and 40 percent by 2020 (2018 for public owned listed companies). In November 2013 the European Parliament decided by majority to support this legislative proposal, which has been subject to further discussion in EU Council in 2014 and it is still in progress.

In this way, the less represented gender should be much more protected and a minimum harmonization within the EU's rules should attract investors that would not suffer the costs associated with regulatory differences among member States. Voluntary actions, as self-corporate governance codes, enjoy greater flexibility, but the facts had clearly demonstrated the inability of the self-discipline alone to promote gender equality.

The presence of women in administrative and supervisory bodies, according to defined quotas by specific provisions or under corporate self-regulation, engages the nomination processes [4].

In the appointment of members of corporate governance bodies, the shareholders' meeting plays a significant and often exclusive role in the mandate to exercise governance decisions and activities. The relationship between the members of administrative and supervisory bodies and the shareholders meeting is a typical agency relationship, founded on the mandate and depending on the different characteristics of corporate governance systems [5] [6] [7] [8] [9]. The appointment procedure is a critical step, subject to external controls by supervisory bodies and to internal controls by company itself.

In particular, in recent years, UE guidelines and recommendations have rested on how to elect corporate governance bodies with regard to the need of protecting shareholders' and other stakeholders' interests.

The existence of rules providing the respect of minimal quotas of female presence on boards implies for the company a risk of non-compliance, from which consequences of various gravity can follow. Specifically, when the rule is binding as legislative measure, the penalty for non-compliance may involve the suspension of any benefits enjoyed by all board members (e.g. Belgium) or the inability for the board to execute activities and, therefore, the cancellation of appointments (e.g. France, Greece, Italy). Similarly, in the 'comply or explain' situation, or in those cases based exclusively on voluntary internal procedures, the noncompliance with rules, if not properly justified, correlates the risk of verification by the control authorities and the possibility of loss of stakeholders' approval.

The appointment of the corporate governance bodies' members is the last step of a process that includes the identification of candidates and the creation of lists of eligible subjects. Therefore, the respect for a fair representation of both sexes on boards must be considered in this moment. A consultative and effective ex-ante control on equitable gender composition of the future corporate governance bodies can be implemented by the board committees.

The board committees are internal organs constituted by groups of non-executive directors and possibly with the 
necessary requirements of independent judgment. They are in the administrative body or in the supervisory body (in the twotier vertical system).

The board committees support the nominating process both in the situations characterized by a wide spread of shares and in the situations where block holders have the majority control. In the first case, the lists' drafting can be difficult because of the high ownership fragmentation and the scarce interest in the voting right. In the second case, minority shareholders and other stakeholders need to be protect guaranteeing the possibility to elect their delegates in the board.

\section{BOARD COMMITTEES' ROLE FOR THE GENDER EQUALITY}

The constitution of the nomination committee in the UE can be a mandatory requirement or a standard recommended by the international and national rules $(2005 / 162 / \mathrm{EC})$. Its aim is to coordinate the establishment of balanced and qualified board, making recommendations to the board with respect to the appointment and removal of directors by the body competent under national company law.

The nomination committee assesses and considers the diversity of the board (in terms of gender, membership of minority groups, etc.) in addition to the balance of knowledge, skills, and experience of the board's members. So, this committee has a fundamental role for the respect of binding rules about gender balance on board and for the promotion of gender equality when norms in this matter lack.

A research conducted in 44 countries and engaging more than 900 board members, intended to highlight the best practices worldwide about the succession in the top positions, CEO in particular [10].

The analysis shows that about 50 percent of board members, both female and male, agree with the statement that decisions about the succession plans of the CEO figure should be subject of discussion of the entire board. However, in practice the 22 percent of cases are entirely managed by nomination committee and the 25 percent of cases by the board President. This research confirms the role of the nomination committee in the promotion of succession plans reflecting board's needs also with regard to gender balance, according to a rational path not pressed by the urgency of the moment.

The constitution of compensation committee supports the board in the definition and realization of remunerative policies for members of corporate governance bodies. This committee is not binding in the EU countries. In particular, the aim of adequate remunerative policies is: to attract human resources; to align the choices of board members with the performance corporate goals; to verify the respect of ethical issues, also in compliance with binding norms (e.g. the same retribution between men and women corresponding to the same position).

The reduction of the so-called 'gender pay gap' has been long on the European agenda [11]: since 1999 it has been part of the European strategy for employment and in 2003 all member States were asked to reduce it. Thanks to European interventions (Directive 2006/54/EC; European Pact for Gender Equality 2011-2020) the 'gender pay gap' as form of direct discrimina- tion is destined to pass away. However, very complex situations exist with indirect discriminatory impacts on remuneration, such as the difficulty to conciliate work and family or the different recognition for the same work done by men and by women.

The audit committee supports the board in the monitoring of internal control system and risk management. It is a binding body in one-tier corporate governance systems and in other specific situations (e.g. in Austria since 2008 for biggest companies). For our purposes, it is important underlying that the audit committee has the task to inform about the risk of noncompliance with rules on gender balance, in case that risk has not been identified or appropriately considered by board of directors.

Considering the role of board committees to guarantee and promote the gender equality on board, it is desirable that a fair representation of both sexes realizes also into the committees themselves.

The mentioned research [10] shows that in 63 percent of cases the members of the committees are subject to regular replacement, while in the remaining cases the committees appear unchanged for long periods, to emphasize the low rotation of the entire board.

Furthermore, women seem to be excluded by the role of board President and CEO, with a higher female presence in the role of non-executive director [1]. Considering that the committees are made for all or the majority of non-executive and independent directors, we expect that many women are appointed as committee members.

A research carried out in 2013 involving 1.371 companies belonging to $S \& P 1500$ [12] shows a low female presence in committees. This research, even if focalized on USA, expresses a generalized immobility of women on boards and this phenomenon is much more amazing in an outsider corporate governance system where the duration of mandates is lower (usually one year) and the replacement of board of directors is frequent.

As an example for European area, we cite the Italian situation, where there are binding rules that impose quotas of women in corporate governance bodies and the UK situation where only recommendations exist for gender diversity in boards of listed companies.

The Table 1 shows the average number of women as members of board committees in Italian listed companies since 2012 (the first year with available data following the introduction of law about female quotas L.120/2011). As we can see in Table 1 , in 2012 women did not even reach the unit where the average number of committee members is three; this situation indicates that in the greater part of Italian listed companies men are the totality of the committee members. However, we can see weak signs of improvement in the period. 
TABLE I. WOMEN IN BOARD COMMITTEES (ITALIAN LISTED COMPANIES 2012 - 2013)

\begin{tabular}{|l|c|c|c|c|c|c|}
\hline & \multicolumn{2}{|c|}{$\begin{array}{c}\text { Companies } \\
\text { with commit- } \\
\text { tees (*) }\end{array}$} & \multicolumn{2}{c|}{$\begin{array}{c}\text { Average number } \\
\text { of committee } \\
\text { members }\end{array}$} & \multicolumn{2}{c|}{$\begin{array}{c}\text { Average num- } \\
\text { ber of women }\end{array}$} \\
\hline & $\mathbf{2 0 1 2}$ & $\mathbf{2 0 1 3}$ & $\mathbf{2 0 1 2}$ & $\mathbf{2 0 1 3}$ & $\mathbf{2 0 1 2}$ & $\mathbf{2 0 1 3}$ \\
\hline $\begin{array}{l}\text { Nomination } \\
\text { committee }\end{array}$ & $20.0 \%$ & $44.4 \%$ & 3.3 & 3.3 & 0.4 & 0.6 \\
\hline $\begin{array}{l}\text { Compensation } \\
\text { committee }\end{array}$ & $88.2 \%$ & $89.5 \%$ & 3.1 & 3.1 & 0.4 & 0.6 \\
\hline $\begin{array}{l}\text { Audit } \\
\text { committee }\end{array}$ & $91 \%$ & $91.2 \%$ & 3.2 & 3.2 & 0.5 & 0.7 \\
\hline
\end{tabular}

(*) On the total of listed companies. Source: Consob (2013), Report on Corporate Governance of Italian Listed Companies, n.2; Consob (2014), Report on Corporate Governance of Italian Listed Companies, n.3. The data for 2014 and 2015 are not available at the moment: the Report 2015 (with data about year 2014) will be published by Consob from $15^{\text {th }}$ December 2015.

In the UK on 2014, 107 women sat on 63 nomination committees of listed companies belonging to FTSE100 index [13]. In 2015 the women were 121 on 71 nomination committee. In both years the average presence of women is 1.7 more than twice the average number in Italy.

\section{GENDER EQUALITY AND VOTING LIST}

The voting list in listed companies was conceived in Italy with the so-called Savings Law (L.262/2005). This institution, which essentially requires listed companies to allow minority shareholders to appoint their representatives in the board of directors, is sufficiently rare in the international scene. As Italy, other countries that impose companies to guarantee representatives of minority shareholders in boards of director are Israel, Spain and Russia [14].

Also European Commission reflects on the peculiarity of Italian legal system in the Green Paper on Corporate Governance (2011).

We do not intend to review benefits and limits of this institution, but rest on the issues regarding gender equality upon lists presentation by minority shareholders. The presence of a higher or lower percentage of women in corporate governance bodies depends on their presence in the candidacy step. In fact, the voting list conditions all the phases of the nomination process and it aims at strengthening the protection of minority shareholders reducing the risk of a governance exclusively oriented to majority shareholders' interests.

The respect of a fair representation of both sexes in the lists presented by minority shareholders can be particularly onerous when the number of candidates is limited. Therefore Consob (which is the control body on Italian Stock Exchange) in 2011 published a consultation document to modify the Issuers Regulation $11971 / 1999$ in the part relating to gender balance. Consob received observations by a variety of subjects (associations and individuals).

Specifically, the question asked by Consob intended to recognize wide autonomy to corporate statutes with regard to the arrangements to comply with the Regulation, coordinating the female quotas with voting list.

At the end of consultation, Consob confirmed the proposal that does not contain provisions regarding the way of lists formation, this last determined by statute. This is in order not to limit society's autonomy considering the different ownership structure of listed companies allowed by Italian law.

The only constraint is to avoid that the company's statute requires the gender balance to lists with less than three candidates. In fact, in the absence of this rule, the shareholders presenting such lists may be required to include at least one additional name belonging to the less represented gender, with a percentage of women exceeding the minimum required by the L.120/2011 and with a considerable costs increase. Furthermore, this criterion is based on the number of candidates in the list and not on the list qualification as a list by minority. This status could not be determined ex ante with reference to certain companies.

The statutory autonomy is guaranteed with regard the way to replace board members ceased during the mandate, considering also the specific ownership structure, to ensure compliance with gender quotas and the minority shareholders protection.

\section{CONCLUSIONS}

European Union data show that since Nineties the percentage of graduate women is always higher than the percentage of graduate men and this trend seems to be confirmed also for the next decades [1]. Therefore, the basin where companies can tap in the research of skills for high level position would seem to favor the choice towards female component, or at least not to discriminate.

Nevertheless, the facts show a different situation putting in evidence that the low presence of women on boards cannot be attributed to a lack of offering, but to cultural obstacles, defense of acquired positions and limited orientation to global management responsibilities.

The previous considerations would seem to point out that the real problem of under representation of women on boards is due to entry selection and to a substantial difficulty in career advancement, in particular with reference to the possibility to fill the role of executive director and chairperson. In fact, in the most cases the largest proportion of women is found as nonexecutive directors or as members of the supervisory board, where the independent judgment typical of these roles dampens the possibility of direct and immediate influence in strategic decisions.

The board committees have an important role both in the appointment of women who could be members of the board and in the promotion of equality of treatment between genders guaranteeing compliance with binding and self-regulatory rules.

Thus, the presence of women in the committees should be maximally favored. Furthermore, the committees seem to be an incredibly good development ground where, because of the smaller audience, the women members (the newly appointed ones in particular) can nurture their specific skills and learn to integrate with board dynamics [13].

The European situation about women on boards shows that the historical, political, economic and cultural rights are the driving force for gender equality not in formal but in substantial manner [15]. At the same way, the real driving force for a substantial gender equality on boards is the corporate culture. 
The binding rules interventions may accelerate the phenomenon but, in the absence of a cultural receptive substrate, they are reduced to sterile and additional tasks that companies deem necessary in the management of compliance risk.

Therefore, the first way of growing and sustaining the female presence in corporate governance bodies is to change the corporate culture and to make the process of appointing new directors transparent and based on the company's accountability towards stakeholders, according with corporate sustainable development in the long-term.

\section{REFERENCES}

[1] European Commission, EC Database on women and men in decisionmaking. Available at: http://ec.europa.eu/justice/gender-equality.

[2] McKinsey \& Company (2010), "Women at the top of corporations: making it happen", McKinsey and Company.

[3] McKinsey \& Company (2013), "Women Matter. Gender diversity in top management: Moving corporate culture, moving boundaries", McKinsey and Company.

[4] OECD (2012), "Board Nomination and Election", Directorate for Financial and Enterprise Affairs, April.

[5] A. A Berle and G. C. Means, The Modern Corporation and Private Property. New York: Macmillan 1933.

[6] A. A Alchian and H. Demsetz (1972), "Production, Information Costs and Economic Organization", The American Economic Review, 62 (5): 777-795, 1972.
[7] E. F. Fama and M. C. Jensen, "Separation of Ownership and Control", Journal of Law and Economics, 26: 301-325, 1983.

[8] O. E. Williamson, The Mechanisms of Governance, Oxford: Oxford University Press, 1996.

[9] D. M. Salvioni and F. Gennari, "Corporate governance, sustainability and capital markets orientation", International Journal of Management and Sustainability, 3(8): 469-483, 2014.

[10] Heidrick and Struggles, 2013 Board of directors survey. The state of leadership succession planning today. Available at: www.heidrick.com.

[11] P. Foubert, S. Burri and A. Numhauser-Henning, The Gender Pay Gap in Europe from a Legal Perspective, EU, 2010. Available at: http://ec.europa.eu/justice/genderequality/files/gpg_legal_perspective_2010_en.pdf

[12] Ernst and Young, Diversity drives diversity. From the boardroom to the C-suite, 2013. Available at: www.wy.com/governance.

[13] Cranfield International Centre for Women Leaders, The Female FTSE Board Report 2015. Available at http://www.som.cranfield.ac.uk/som/dinamiccontent/research/ftse/FemaleFTSEReportMarch2015.pdf

[14] OECD - Directorate for Financial and Enteprise Affairs - Corporate Governance Committee, Peer review 4: Board Nomination and Election, april 2012.

[15] F. Gennari, L'uguaglianza di genere negli organi di corporate governance (in Italian). Milan: FrancoAngeli 2015. 